\title{
環境省「サーベイランス調査」と「ソラダス」にみる $\mathrm{NO}_{2}$ 大気污染とぜん息有症率の関係
}

西川榮一*

\author{
$\mathrm{NO}_{2}$ pollution effect to asthma prevalence shown by Ministry of the \\ Environment "Reports of environmental health surveillance for air pollution" \\ and by citizens' initiative "SORADASU"
}

Eiichi NISHIKAWA

\section{摘 要}

3 歳児と 6 歳児を対象に, 環境省は毎年大規模な大気污染健康影響調査（「サーベイランス調査」）を 実施している。その年度報告書をみると「大気污染物質濃度が高くなるほどぜん息有症率が高くなるよ うな関連性を示す結果はみられなかった」とまとめられている。このまとめに疑問を感じ, 本稿で同報 告書におけるデータの取り扱い, $\mathrm{NO}_{2}$ 濃度とぜん息有症率の関連性に関する解析について調べた。その 結果同報告書のまとめとは異なり， $\mathrm{NO}_{2}$ 濃度とぜん息有症率は明らかな正の相関関係にあることがわ かった。なぜ環境省報告書と本稿で異なった結果になるのか, その原因も調べた。大阪では, 住民らに よって「ソラダス」と呼ばれる環境調査が続けられているが, その調査においても $\mathrm{NO}_{2}$ 濃度とぜん息有 症率の間に, 正の相関関係が見出されていることを紹介した。そして「サーベイランス調査」と「ソラ ダス」, 両調査が示す結果から現在の $\mathrm{NO}_{2}$ 大気污染が提起する課題について述べた。

キーワード：大気污染健康影響，環境省「サーベイランス調査」，二酸化窒素濃度，ぜん息有症率，

大阪住民調査「ソラダス」

\section{1. 緒 言}

「大気污染に係る環境保健サーベイランス調査」 （以下では「サーベイランス調査」と略記する）と は, 環境省による疫学調査のことで, 3 歳児 (1996 年度から）および 6 歳児 (2004 年度から), それぞ れ 8 9 万人を対象に, 北海道旭川市から沖縄県那 覇市に至る全国 38 地域（6 歳児 2014 年度の場合） において，毎年実施されている広域かつ長年にわ たる極めて大規模な継続調査である。したがって その結果は大気污染対策や健康被害対応など大気 環境行政にも少なからず影響すると思われる。
「サーベイランス調査」の結果は毎年報告書が作 成され，環境省ウエブサイトでも公開されている。 2014 年度の調査報告書（環境省環境保健部 2016, 以下本稿では「調査報告 H26」と略称する）をみ ると, その結論部分で「3 歳児調查, 6 歳児調査の いずれでも大気污染物質濃度が高くなるほどぜん 息有症率が高くなるような関連性を示す結果はみ られなかった。とまとめられている。調查された 大気污染物質には二酸化窒素 $\left(\mathrm{NO}_{2}\right)$ も含まれてい る。しかし $\mathrm{NO}_{2}$ は呼吸器系に健康影響をもたらす として重視されてきた。早くから環境基準が定め られ, 現在もなお自動車 $\mathrm{NOx} \cdot \mathrm{PM}$ 法などさまざま

\footnotetext{
*元・神戸商船大学， $=594-0031$ 大阪府和泉市伏屋町 4-3-22, e-nishikawa@dab.hi-ho.ne.jp
} 


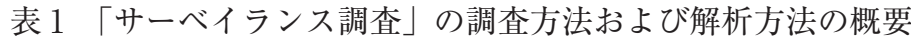

\begin{tabular}{|c|c|c|}
\hline \multicolumn{3}{|r|}{ 調査の対象および調査方法 } \\
\hline 調査対象者 & \multicolumn{2}{|c|}{$\begin{array}{l}3 \text { 歳児 }(1996 \text { 年度から) と6歳児 }(2004 \text { 年度から) それぞれ } 8 \text { 万〜 } 9 \text { 万 } \\
\text { 人、毎年度継続調査 }\end{array}$} \\
\hline 調査対象地域 & \multicolumn{2}{|c|}{ 北海道旭川市〜沖縄県那覇市 38地域（6歳児2014年度の場合） } \\
\hline (1) 環境調査 & \multicolumn{2}{|c|}{$\begin{array}{l}\text { 各調查対象地域3次メッシュの大気污染物質 }\left(\mathrm{SO}_{2} 、 \mathrm{NO}_{2} 、 \mathrm{NO}_{\mathrm{x}} \text { 、 }\right. \\
\mathrm{SPM}) \text { 年平均濃度（「調査報告」は背景濃度と呼んでいる）を、 } \\
\text { 一般環境大気測定局のデータを基に推定で求める }\end{array}$} \\
\hline (2) 健康調査 & \multicolumn{2}{|c|}{$\begin{array}{l}\text { ATS-DLD質問票に基づいた調査票を用い、3歳児は健診診査におい } \\
\text { て、6歳児は小学校でデータを収集。住所から対象者の3次メッシュ } \\
\text { を特定している。 }\end{array}$} \\
\hline \multicolumn{3}{|c|}{ データの解析方法 } \\
\hline \multirow{2}{*}{$\begin{array}{l}\text { データ分析の } \\
\text { 枠組み }\end{array}$} & \multicolumn{2}{|c|}{$\begin{array}{l}\text { 当該年度単年データの分析、および単年でなく継続調査されてきた } \\
\text { 年次データ全体をまとめた分析を行っている }\end{array}$} \\
\hline & \multicolumn{2}{|c|}{$\begin{array}{l}\text { 行われている解析方法は、地域データを利用した地域横断的解析と } \\
\text { 年次データを利用した経年縦断的解析に大別できる } \\
\end{array}$} \\
\hline \multirow{4}{*}{$\begin{array}{l}\text { 地域データに } \\
\text { よる地域横断 } \\
\quad \text { 的解析 }\end{array}$} & \multicolumn{2}{|c|}{$\begin{array}{l}\text { 各調査地域の(1)と(2)のデータの組合せ解析によって背景濃度と呼 } \\
\text { 吸器系症状有症率との関係を調べる。解析は下記の } 3 \text { つの方法 }\end{array}$} \\
\hline & 解析 A & 対象者別背景濃度区分と呼吸器系症状有症率との関係 \\
\hline & 解析 B & $\begin{array}{l}\text { 調査地域ごとの対象者別背景濃度平均值と呼吸器系症状 } \\
\text { 有症率との関係を調べている(本稿ではこれら調査地域 } \\
\text { ごとのデータを地域データと呼ぶ) }\end{array}$ \\
\hline & 解析 C & オッズ比による検討 \\
\hline \multirow{2}{*}{$\begin{array}{l}\text { 年次データに } \\
\text { よる経年縦断 } \\
\quad \text { 的解析 }\end{array}$} & 解析 D & $\begin{array}{l}\text { 年次データを利用して污染物質濃度や有症率などの経年 } \\
\text { 的動向を見ている。組合せ解析は行っていない } \\
\end{array}$ \\
\hline & 解析 $\mathrm{E}$ & $\begin{array}{l}3 \text { 歳児と } 6 \text { 歳児データを利用して対象者の追跡調査を } \\
\text { 行っでん息発症率を調べている }\end{array}$ \\
\hline
\end{tabular}

な対策が講じられてきている污染物質である。し かるになぜ $\mathrm{NO}_{2}$ の健康影響を否定するかのような 結果が得られたのか, 「調査報告 H26」を調べてみ た。著者が調べた内容の簡単な要旨はすでに別報 （西川 2018）に述べてあるが,ここでは内容全体を 詳細に報告する。これが本稿 1 つめの目的である。

大阪では「ソラダス」と呼ばれる $\mathrm{NO}_{2}$ 測定運動 が行われている（久志本ら 2013）。この運動は, $\mathrm{NO}_{2}$ 簡易測定法（西川ら 1999）を用い, 住民の手 で大阪府全域にわたって大気中の $\mathrm{NO}_{2}$ 濃度を測 定する運動である。およそ 5 年ごとに取り組まれ, 2016 年には第 8 回が実施された。「ソラダス」で は $\mathrm{NO}_{2}$ 測定と並行して, ATS-DLD 質問票 ${ }^{1)}$ に基 づいたぜん息など呼吸器系の健康状態をたずねる 健康アンケートも行われてきた。最近では測定対 象域全域から健康アンケート回答が収集されるよ うになったので, $\mathrm{NO}_{2}$ 濃度測定デー夕と健康状態 の関係を調べることが可能になってきた（久志本 2018）。「ソラダス」は大阪住民の自主運動で,「サー
ベイランス調査」とは関係なく実施されてきた測 定運動であるが，両者は基本的には同じとみられ る調查方法が取られており興味深い。そこで「ソ ラダス」のデータによって得られた $\mathrm{NO}_{2}$ 濃度とぜ ん息有症率の関係について述べる。これが本稿 2 つめの目的である。

そして「サーベイランス調査」だけでなく,「ソ ラダス」も合わせて，2つの調査結果が示す $\mathrm{NO}_{2}$ 濃度とぜん息有症率の関連について検討し, 現在 の $\mathrm{NO}_{2}$ 污染がどのような問題を提起しているの か考えてみたい。これが本稿 3 つめ目的である。

\section{2.「サーベイランス調査」の調査方法とデー タの分析}

\section{1 「サーベイランス調査」の枠組み}

「調查報告 $\mathrm{H} 26 」$ をみてサーベイランス調査」 の枠組みをまとめると表 1 となる。環境調査は 4 つ の污染物質 $\mathrm{NO}_{2}, \mathrm{NOx}, \mathrm{SO}_{2}, \mathrm{SPM}$ のデータを収 集している。健康調査は呼吸器系症状の質問とと 
表 2 調査対象地域の要目および『地図表示』から読み取った特徵

\begin{tabular}{|c|c|c|c|c|c|}
\hline 調査対象地域 & $\begin{array}{l}\text { 面積 } \\
\mathrm{km}^{2}\end{array}$ & $\begin{array}{c}\text { 大気測定 } \\
\text { 局*** }\end{array}$ & $\begin{array}{l}\begin{array}{l}\text { 対象者·有症者の分布状態, 局所的 } \\
\text { 污染源など* }\end{array} \\
\end{array}$ & $\begin{array}{l}18^{\circ} \mathrm{C} \text { デグ } \\
\text { リーデー** }\end{array}$ & ブロック \\
\hline 小樽市 & 244 & 3地点 & 対象者, 有症者が部分域に分布 & 3648 & 北海道 \\
\hline 旭川市 & 748 & 5地点 & 対象者, 有症者が部分域に分布 & 4237 & 北海道 \\
\hline 釧路市 & 1363 & 2地点 & 対象者, 有症者が部分域に分布 & 4393 & 北海道 \\
\hline 八戸市 & 306 & 4地点 & 対象者, 有症者が部分域に分布 & 3138 & 東北 \\
\hline 秋田市 & 906 & 7地点 & 対象者, 有症者が部分域に分布 & 2667 & 東北 \\
\hline 横手地域 & 861 & 1地点 & 有症者が道路近傍メッシュに多い & 3107 & 東北 \\
\hline 佐野市 & 356 & 2地点 & $\begin{array}{l}\text { 対象者は部分域に分布, その中で } \\
\text { 有症者は道路近傍メッシュに多い }\end{array}$ & 2237 & 関東 \\
\hline 草加市 & 27.5 & 1地点 & 対象者も有症者もほぼ全域に分布 & 1950 & 関東 \\
\hline 千葉市中央·花見川区 & 79 & 6地点 & $\begin{array}{l}\text { 花見川区は有症者が道路近傍メッ } \\
\text { シュに多い, 中央区は前面に製鉄 } \\
\text { 所など臨海工業域 }\end{array}$ & 1898 & 関東 \\
\hline 柏・我孫子市 & 158 & 3地点 & 対象者も有症者もほぼ全域に分布 & 2018 & 関東 \\
\hline 墨田区 & 13.8 & なし & 対象者も有症者もほぼ全域に分布 & 1742 & 関東 \\
\hline 中野区 & 15.6 & 1地点 & 対象者も有症者もほぼ全域に分布 & 1742 & 関東 \\
\hline 横浜市鶴見区 & 33.2 & 2地点 & 対象者も有症者もほぼ全域に分布 & 1668 & 関東 \\
\hline 川崎市幸区 & 10 & 1地点 & 対象者も有症者もほぼ全域に分布 & 1668 & 関東 \\
\hline 相模原市 & 329 & 5地点 & 対象者が東部の部分域に分布 & 1900 & 関東 \\
\hline 高岡市 & 210 & 2地点 & 対象者は東半分域に分布 & 2216 & 甲信北陸 \\
\hline 甲府市 & 212 & 1地点 & 対象者は中心域に分布 & 2078 & 甲信北陸 \\
\hline 松本市 & 978 & 1地点 & 対象者が中心域に分布 & 2844 & 甲信北陸 \\
\hline 岐阜市 & 204 & 3地点 & 対象者も有症者もほぼ全域に分布 & 1798 & 中部東海 \\
\hline 大垣市 & 207 & 2地点 & 対象者が東部域に多い & 1791 & 中部東海 \\
\hline 名古屋市港·南区 & 64 & 2地点 & 対象者も有症者もほぼ全域に分布 & 1773 & 中部東海 \\
\hline 安城市 & 86 & 3地点 & 対象者も有症者もほぼ全域に分布 & 1913 & 中部東海 \\
\hline 東海市 & 43.4 & 5地点 & 前面に臨海域に製鉄工場地域 & 1741 & 中部東海 \\
\hline 四日市市 & 206 & 7地点 & 対象者も有症者も & 1835 & 中部東海 \\
\hline 大阪市淀川・西淀川区 & 26.9 & 2地点 & 対象者も有症者もほぼ全域に分布 & 1650 & 関西 \\
\hline 堺市堺区 & 23.7 & 2地点 & 対象者も有症者もほぼ全域に分布 & 1774 & 関西 \\
\hline 大東市 & 18.3 & 1地点 & 対象者も有症者もほぼ全域に分布 & 2000 & 関西 \\
\hline 神戸市灘・兵庫区 & 47.3 & 3地点 & 対象者も有症者もほぼ全域に分布 & 1679 & 関西 \\
\hline 尼崎市 & 50.7 & 3地点 & 対象者も有症者もほぼ全域に分布 & 1679 & 関西 \\
\hline 西宮・芦屋市 & 118 & 9地点 & 対象者も有症者もほぼ全域に分布 & 1679 & 関西 \\
\hline 和歌山市 & 209 & 7地点 & $\begin{array}{l}\text { 対象者も有症者も海側に分布。臨 } \\
\text { 海域に製鉄工場地域 }\end{array}$ & 1549 & 関西 \\
\hline 広島市安佐南区 & 117 & 2地点 & 対象者も有症者もほぼ全域に分布 & 1800 & 中国 \\
\hline 宇部・山陽小野田市 & 420 & 5地点 & $\begin{array}{l}\text { 対象者が南部臨海域に多い。臨海 } \\
\text { 域にセメントなど工場群 }\end{array}$ & 1801 & 中国 \\
\hline 北九州市八幡西区 & 83.1 & 2地点 & 北部近傍に金属·製鉄関連工場地带 & 1646 & 九州沖縄 \\
\hline 福岡市南区 & 31 & 1地点 & 対象者も有症者もほぼ全域に分布 & 1455 & 九州沖縄 \\
\hline 島原地域 & 467 & 1地点 & $\begin{array}{l}\text { 有症者は対象者分布の中の道路沿 } \\
\text { 道メッシュに多い }\end{array}$ & 1383 & 九州沖縄 \\
\hline 大分市 & 502 & 12地点 & $\begin{array}{l}\text { 対象者は海側）に多く，前面に製 } \\
\text { 鉄など臨海工場地帯 }\end{array}$ & 1575 & 九州沖縄 \\
\hline & 3 & 1地点 & 対象者も有症者もほぼ全域 & & \\
\hline
\end{tabular}

*)「調查報告H26」に示されている『地図表示』から，著者が読み取った内容

**) $18^{\circ} \mathrm{C}$ デグリーデーは，基準温度を $18^{\circ} \mathrm{C}$ し，日平均気温が $10^{\circ} \mathrm{C}$ 以下の日の, $18^{\circ} \mathrm{C}$ と日平 均気温との差の積算值。データはHEAT20(2017)から引用。

***) 設置測定局のうち実際に2014年度の年平均值が示されている測定局の地点数

もに，住所と居住歴，住居の構造，喫煙，暖房方 法, ペットの有無, アレルギー症既往歴など関連す るさまざまな属性についても質問している。データ の解析は 38 か所の調查対象地域のデー夕を利用す る地域横断的解析と, 蓄積されてきた年次データ (2014 年度までで 3 歳児は 18 年分, 6 歳児は 11 年
分）を利用する経年縦断的解析に大別できる。

「調查報告 H26」では 3 歳児, 6 歳児, 性別, さ まざまな呼吸器系症状, $\mathrm{NO}_{2}$ のほか $\mathrm{NOx}, \mathrm{SO}_{2}$, $\mathrm{SPM}$ の大気污染物質など多岐にわたるケースに ついて分析されているが, どのケースも同じ方法, 内容で解析されている。本稿では，主に 6 歳児に 
関する $\mathrm{NO}_{2}$ 濃度とぜん息有症率のデー夕を取り 上げることで,「調査報告 H26」のデータ収集やそ の解析方法について調べることとする。

38 調査対象地域の要目などを表 2 に示す。「調 査報告 H26」には『地図表示』として, 3 次メッ シュの格子線を入れた各調査対象地域の地図を示 し, 各メッシュの $\mathrm{NO}_{2}$ 濃度は塗りつぶしのカラー で表し, 対象者および有症者の数は円グラフのサ イズで表し，そして一般大気測定局の位置も記入 したカラー図面が掲載されている。表 2 の左から 4 つめの欄（対象者・有症者の分布状態, 局所的 污染源など）は，この『地図表示』から著者が読 み取った各地域の特徴である。サーベイランス調 査」の大きな特徵の 1 つは, 調査対象地域が広域 にわたっていることである。表 2 に示した $18^{\circ} \mathrm{C} テ ゙$ グリーデー值 ${ }^{2)}$ は各地域の気候条件を表す指標の 1つとして著者が加えたものである。

\section{2 データの収集, 取扱いに関する問題点}

表 1 , 表 2 をみると, いくつかの問題点が指摘 される。

(1) 3 次メッシュの濃度推定は精度が低く, かつ 局所的な污染が的確に捉えられていない

3 次メッシュ（約 $1 \mathrm{~km}$ 四方の格子区画）の濃度 は, 一般環境大気測定局の年平均デー夕を基にし て, 空間的に補間する方法で推定されている。こ の方法では, 調査対象地域全体の平均濃度は測定 局のデータが反映されるだろう。しかしメッシュ 数 $\left(\mathrm{km}^{2}\right.$ 面積にほぼ等しい) と比べて, データ利 用可能な一般大気環境測定局の数は表 2 にみるよ うにわずかであり, 各メッシュの濃度推定の精度 は高くないと考えられる。またこの方法では幹線 道路沿道など局所的な污染は的確に捉えられな w。

(2)有症率のデータに対する局所的污染影響の有 無を検討する必要がある

調查対象地域内で自動車交通など局所的な污染 があって健康影響が生じている場合, 健康調查の データにはその影響が反映されるだろう。しかし 環境調査のデータには，(1)に述べたように沿道局 所污染は的確に捉えられていないから, 健康影響 と污染濃度との関係を正しく解析できないおそれ がある。
(3)アレルギー症既往歴の影響の調整には注意を 要する

健康調査では性別, 喫煙, 家屋構造, 暖房, ペッ ト,アレルギー症既往歴など, 大気污染以外のさ まざまな影響要因のデータが収集されている。解 析Cのオッズ比の場合はそれらの影響が検討され ているが, 他の解析ではほとんど検討されていな い。ただし性別およびアレルギー症既往歴につい ては考慮されている。性別についてはデー夕を男 女別に分けて分析している。アレルギー症既往歴 については以下の方法がとられている。

「調查報告 H26」は, 対象者のアレルギー症既往 歴の有無を(1)本人・親ともになし, (2)親のみあり, (3)本人のみあり, (4)本人・親ともにあり, の 4 夕 イプに分けてぜん息有症率に対するアレルギー症 既往歴の影響を調べている。たとえば 6 歳児 2014 年度の場合の結果をみるとタイプ別ぜん息有症率 は (タイプ(1)を 1 とした相対值), (2) 2.1, (3) 2.45, (4) 4.46 となっており, 夕イプによって大きく変化 している。このことは, 調査対象地域のぜん息有 症率に対して, 各タイプの人数割合が影響を及ほ していることを意味する。そこで「調査報告 H26」 は, 個々の調査対象地域のぜん息有症率を, 各夕 イプの人数割合が全調查対象地域の平均人数割合 に相応するように調整している。「調査報告 H26」 はこのような方法で調整した有症率を調整率と呼 んでいる。取り上げたアレルギー症は,

本人;アレルギー性鼻炎, じんましん,アトピー 性皮膚炎, アレルギー性結膜炎の 4 症,

親; 小児ぜん息, 気管支ぜん息, アトピー性皮 膚炎, 花粉症の 4 症

であり， 4 症のうちどれか 1 つでも既往歴があ れば既往歴ありとしている。この調整方法は, 取 り上げたアレルギー症の既往歴と $\mathrm{NO}_{2}$ 濃度との 間に相関が存在しなければ適用可能である。しか し「調査報告 H26」に示されているアレルギー症 既往歴のデー夕をみると図 1 のようであり，本人 のアレルギー性鼻炎既往歴，親の花粉症既往歴は $\mathrm{NO}_{2}$ 濃度によって変化し, $\mathrm{NO}_{2}$ 濃度の低いところ で低下が大きい。このため $\mathrm{NO}_{2}$ 濃度の低い調查対 象地域では調整率が高くなっている。とくに花粉 症の影響が大きい。アレルギー症既往歴について は何らかの調整が必要であろうが, 「調査報告 $\mathrm{H}$ 


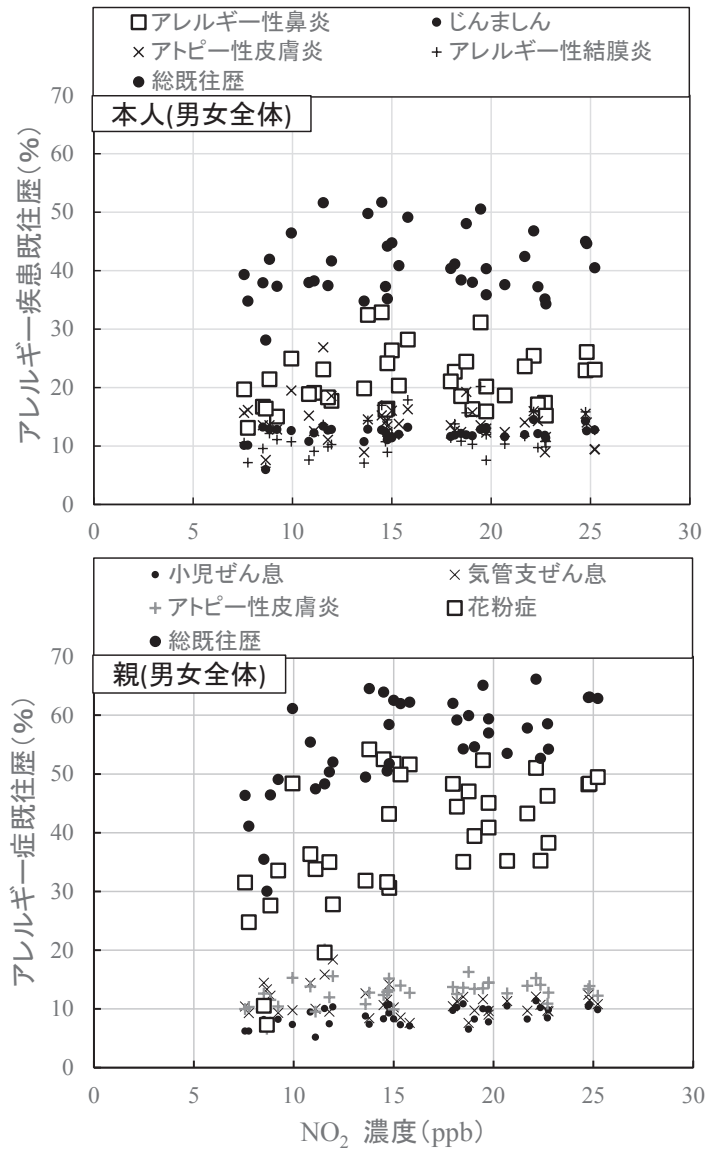

図 1 調査地域ごとの各アレルギー症既往歴およ び総アレルギー症既往歴と調查地域平均 $\mathrm{NO}_{2}$ 濃度との関係. (「調査報告 $\mathrm{H} 26$ 」付録 データから著者が作図）

26」の方法を適用するとしてもアレルギー症既往 歴と $\mathrm{NO}_{2}$ 濃度との間に相関がない範囲に限るべ きであろう。

(4)調查対象地域の地域特性がもたらす交絡影響 が考虑されていない

調查対象地域は北海道〜沖縄県にわたってお り, 地域特性がもたらす交絡要因を考慮する必要 があると思われるが,「調査報告 H26」ではほとん ど検討されていない。たとえば気候の相違である。 表 2 にはその 1 つ指標として $18^{\circ} \mathrm{C}$ デグリーデー の值を示したが，その相違は暖房や換気の状態に 影響するから, 屋内空気污染や曝露程度に関わっ て健康影響をもたらす可能性があろう。
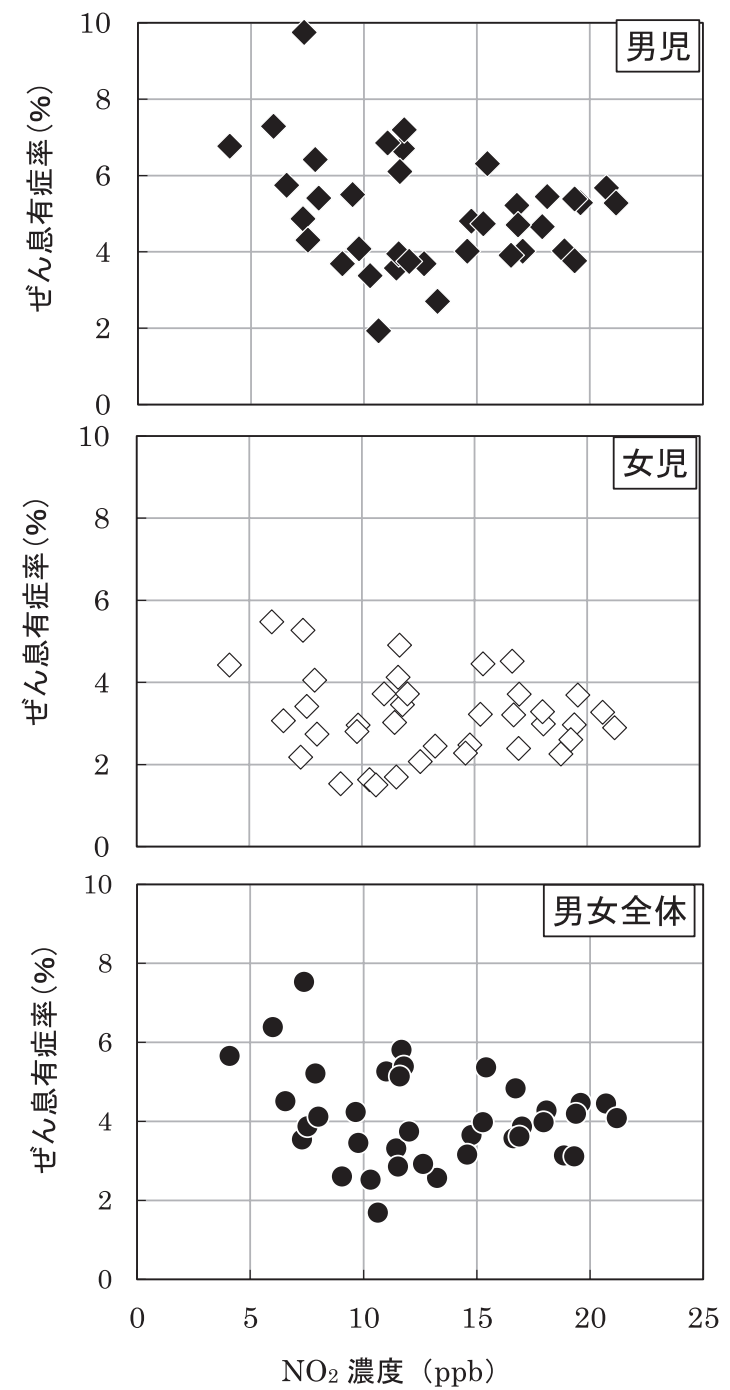

図 2 地域データでみた $\mathrm{NO}_{2}$ 濃度とぜん息有症率 (調整率) の関係.

(6 歳児 2014 単年度, 「調査報告 H26」から 引用)

3.「調査報告 $\mathrm{H} 26\rfloor$ NO $\mathrm{N}_{2}$ 濃度とぜん息有症 率の組合せ解析を調べる

3.1 地域データを利用した $\mathrm{NO}_{2}$ 濃度とぜん息有 症率の地域横断的組合せ解析 (表 1 解析 B)

図 2 は「調査報告 H26」に示された組合せ解析 の 1 つで, 38 調查対象地域それぞれのデー夕を利 用した $\mathrm{NO}_{2}$ 濃度とぜん息有症率の散布図である。 「調查報告 H26」はこの図などに基づいて, 冒頭引 用したように, $\mathrm{NO}_{2}$ 濃度が高くなるとぜん息有症 

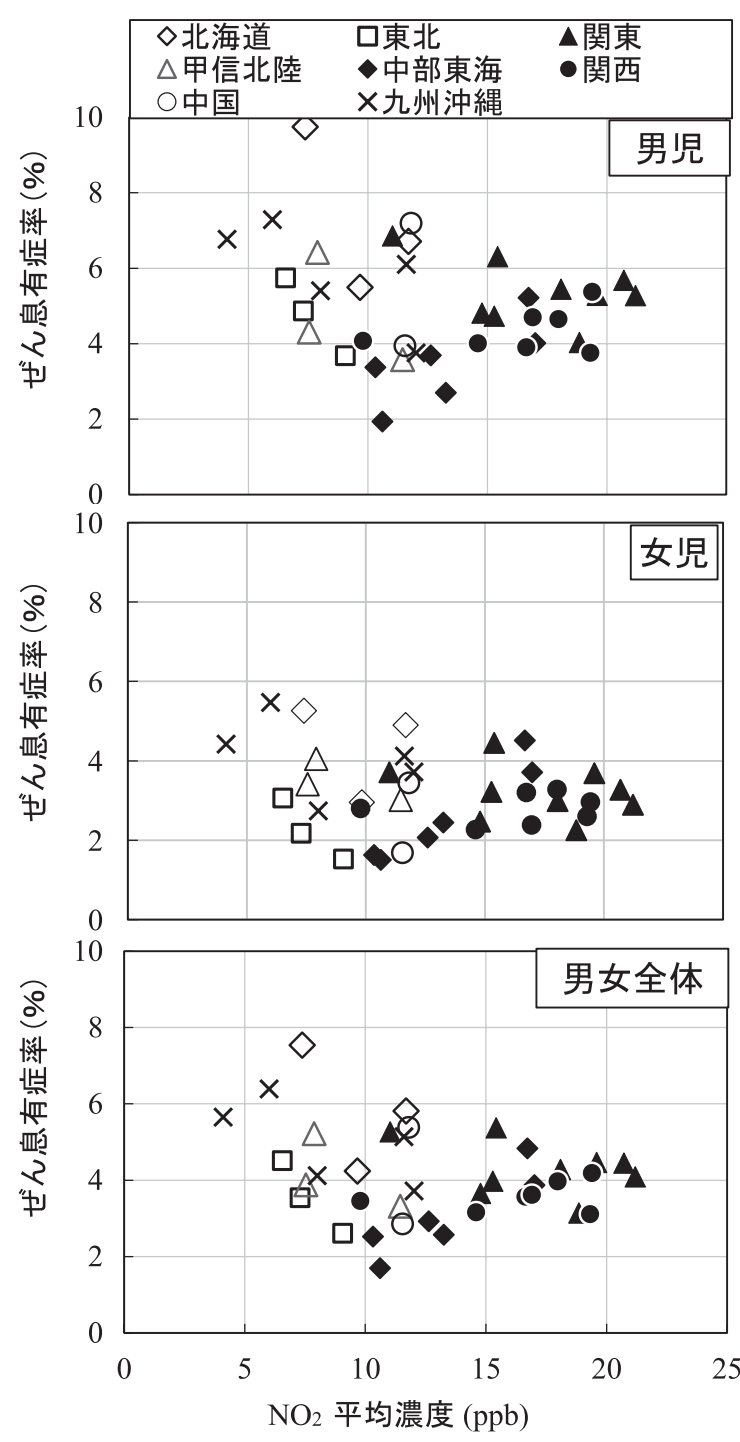

図 3 地域データでみた $\mathrm{NO}_{2}$ 濃度とぜん息有症率 (調整率) の関係.

(6 歳児 2014 単年度, 図 2 の 38 地域を 8 ブ ロックに区別して表示)

率が高くなるような関連性はみられなかったとし ている。確かに図をみると, 男児, 女児, 男女全 体のいずれもバラバラに散らばっている。小野 （2014）は負の相関（ $\mathrm{NO}_{2}$ 濃度が高くなるとぜん息 有症率が低下する) がみられたとさえ述べている。

図 2 は 38 地域のデータが区別なく一括でプロッ トされたものであるが, 38 の調査対象地域は広域 に分散しており, 気候条件も大きく異なる。そこ で 38 地域を, 気候条件を考慮して表 2 に示した 8
ブロックに分けてプロットしてみると図 3 とな る。 $\mathrm{NO}_{2}$ 濃度が同じレベルでもブロックや地域に よって有症率は大きく異なり，地域特性による交 絡要因が影響していることをうかがわせる。図 3 をみて気候は主要因の 1 つと推測されるが, 他に も人口，道路網，土地利用などさまざまな要因が 考えられる。

8 ブロックの中でム関東, \中部東海, ○関西ブ ロックの有症率は同じレベルにあり, かつ $\mathrm{NO}_{2}$ 濃 度が高くなると有症率も高くなる傾向が読み取れ, 注目される。なお男児と女児を比べると,女児の有 症率は男児より低いのだが, 上述した有症率の分 布の様子は男児と女児で大差ないとみられよう。

以上のように地域デー夕には地域特性がもたら す交絡影響が含まれており，それを考慮しないま まの図 2 では, $\mathrm{NO}_{2}$ 濃度とぜん息有症率の関連性 を正しく読み取るのは難しい。地域データを利用 して組合せ解析を行うのであれば，地域特性がも たらす交絡影響を回避する必要がある。

\section{2 対象者別 $\mathrm{NO}_{2}$ 濃度区分とぜん息有症率の関} 係 (表 1 解析 A)

「調查報告 H26」では表 1 に示した解析 A，すな わち全対象者を, 調査対象地域に関係なく, それ ぞれが居住する 3 次メッシュの濃度ランクによっ て区分し，濃度ランクとぜん息有症率の関係を調 べている。図 4 がその結果であるが, 男児, 女児, 男女全体とも $\mathrm{NO}_{2}$ 濃度に対するぜん息有症率の変 化は同じ傾向を示している。図 4 をみて「調査報 告 H26」は, 2014 単年度データについては「濃度 区分が高くなるほどぜん息有症率が高くなる傾向 はみられなかった。窒素酸化物 $\left(\mathrm{NO}_{2}, \mathrm{NOx}\right)$ にお いては, 一定レベル以上の大気污染物質濃度を示 す地域においてぜん息有症率が高い地域がみられ る一方, 濃度レベルの低い地域でもぜん息有症率 が高い地域がみられた。前者は関東，関西の大都 市で，後者は九州・沖縄地区であるが，これらの 傾向は 3 歳児調査および 6 歳児調查において一貫 してみられている」，また図 4 下図の 11 年間をま とめたデータについては「大気污染物質濃度が高 い地域の方が低い地域よりぜん息有症率が高くな る傾向はみられず, 大気污染物質濃度の低い地域 においても大気污染物質濃度が高い地域と同程 
（6歳児2014単年度、図2の38地域を8ブロックに区別して表示）
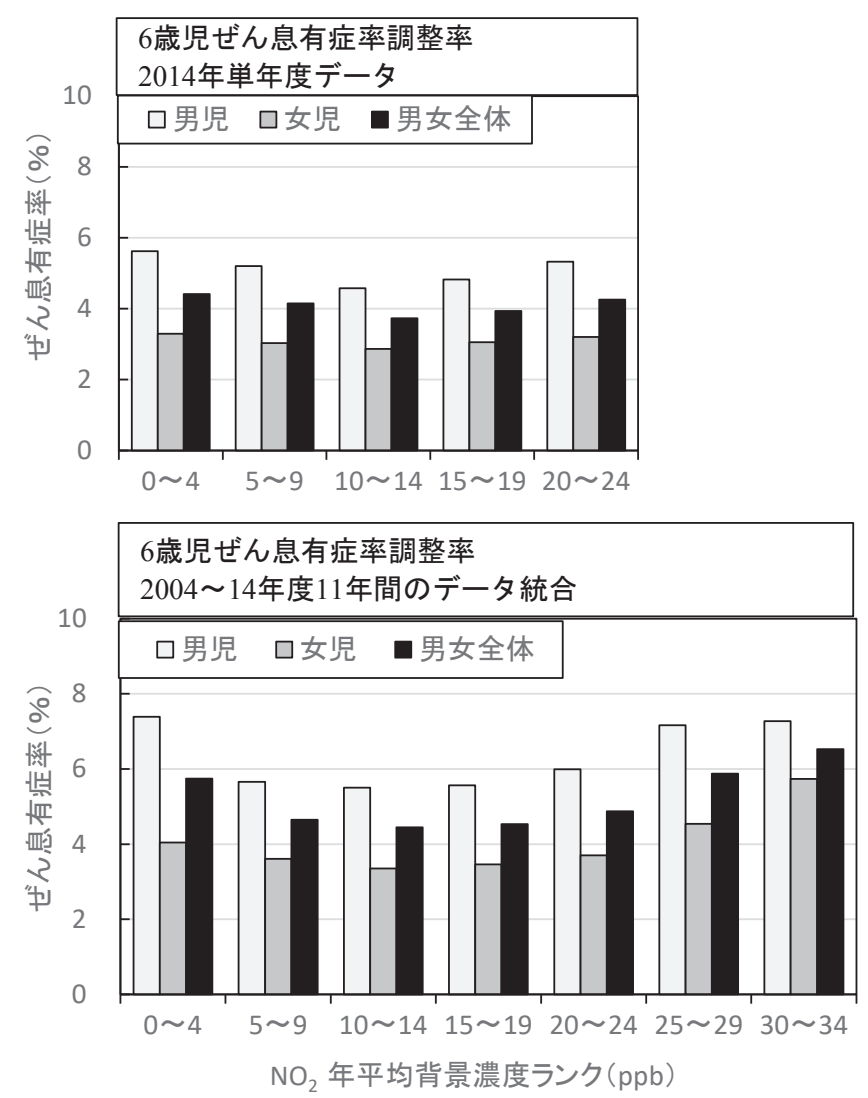

図 4 対象者別 $\mathrm{NO}_{2}$ 濃度ランクとぜん息有症率（調整率）の関係.

(「調查報告 $\mathrm{H} 26 」$ 付録データから著者が作図)

度，またはそれ以上の有症率を示す地域がみられ た」（下線は引用者が加えた）と述べ, $\mathrm{NO}_{2}$ 影響は みられないと読み取れるような評価をしている。

しかし図 4 に示されたデー夕は，上述した地域 特性がもたらす交絡影響が除かれていない。図 4 で $\mathrm{NO}_{2}$ 濃度の低い, とくに $10 \mathrm{ppb}$ 以下のデータ は, 図 3 をみればわかるように, 多くは北海道, 東北など $\mathrm{NO}_{2}$ 濃度は低いがぜん息有症率は高い 地域のデータであり, 既述のように, それらは地 域特性の影響やアレルギー症既往歴の調整の影響 によって有症率が高くなっている。したがって 10 $\mathrm{ppb}$ 以下のレベルのデータは区別すべきである。 このような影響を考慮しないまま, 図 4 によって $\mathrm{NO}_{2}$ 濃度とぜん息有症率の関係を評価するのは不 適切である。

\section{3 年次データを利用した $\mathrm{NO}_{2}$ 濃度とぜん息有} 症率の経年縦断的組合せ解析

地域デー夕には地域特性がもたらす交絡影響が 含まれていることがわかった。その点年次データ を利用した経年縦断的解析であれば，同じブロッ クあるいは同じ調査対象地域についての解析であ るから, 地域特性に起因する交絡影響を回避でき る可能性が高い。「サーベイランス調査」では長期 継続調査によって年次データが蓄積されており, 経年縦断的解析が可能である。

「調查報告 H26」は年次データを用いて, 污染物 質濃度やぜん息有症率の経年的推移を調べている が（表 1 の解析 D)，しかし $\mathrm{NO}_{2}$ 濃度とぜん息有 症率の関係を調べる経年縦断的組合せ解析は行っ ていない。そこで本稿で年次デー夕を利用して 6 歳児デー夕について組み合わせ解析を行った。な お図 2〜4では男児，女児，男女全体それぞれの 


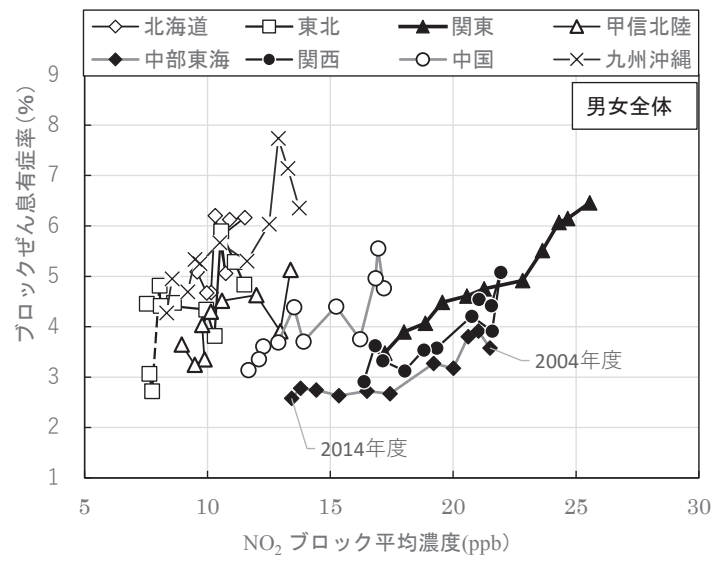

図 52004 2014 年 11 年間の年次データでみた 8 ブロック別の $\mathrm{NO}_{2}$ 平均濃度とぜん息有症率 (調整率) の関係.

データについてもみてきたが, $\mathrm{NO}_{2}$ 濃度に対する 変化の傾向は男児，女児ほとんど同じなので，以 下では男女全体のデータだけを示すことにする。

図 5 がその結果で, 11 年間（2004〜2014 年度） の年次デー夕を用いてブロックごとの $\mathrm{NO}_{2}$ 平均濃 度とぜん息有症率を求め, 両者の経年変化の関係 をみたものである。この 11 年間, どのブロックも, 増減の変動はあるが, 全体としては $\mathrm{NO}_{2}$ 濃度の減 少に伴ってぜん息有症率が低下してきてきた経過 が読み取れる。そして地域データでみた図 2 とは大 きく異なり, 年次データでみると $\mathrm{NO}_{2}$ 濃度とぜん 息有症率の間には明瞭な正の相関が表れている。

各ブロックを比較すると, 同レベルの $\mathrm{NO}_{2}$ 濃度 に対して北海道，東北，甲信・北陸，九州・沖縄 のぜん息有症率が高く，中間に中国ブロックが あって，低いブロックとして関東，中部・東海, 関西が位置している。このようなブロック間の差 異は, 図 3 に表れていた調查対象地域間のそれと 同じであるが，年次データでみると一層明らかで ある。有症率が高いブロックをみると, 北海道, 東北, 甲信・北陸と 3 つまでが寒冷地域である。 また関東，中部東海，関西はぜん息有症率と $\mathrm{NO}_{2}$ 濃度との関係はほぼ同じ変化を示し, $\mathrm{NO}_{2}$ 濃度の 低下とともにぜん息有症率も低下してきた経過が 明瞭に読み取れる。

ブロックに分けないで, 38 調查対象地域のデー 夕全部を 1 つにまとめた $\mathrm{NO}_{2}$ 平均濃度とぜん息有

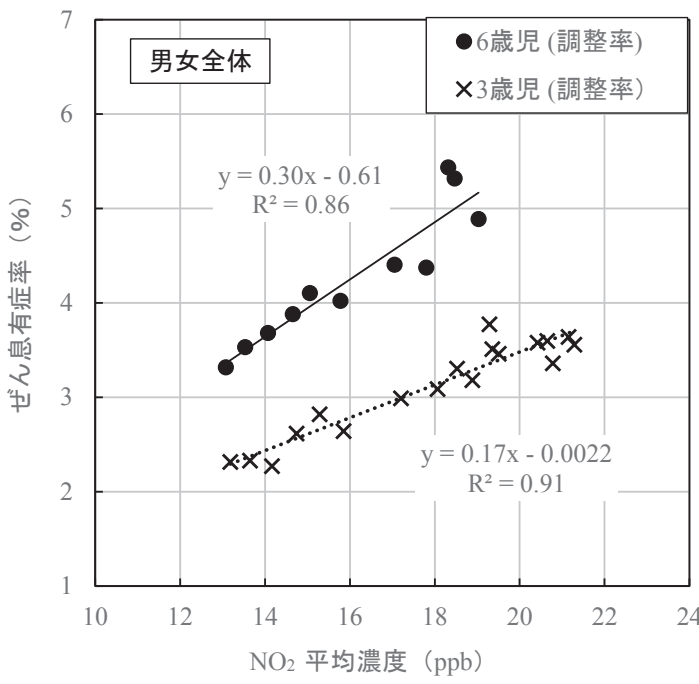

図 6 年次データでみた全調査対象地域の平均 $\mathrm{NO}_{2}$ 濃度とぜん息有症率 (調整率) の関係. （3 歳児は 1997～2014，6 歳児は 2004～2014 の 年次データ,「調査報告 H26」の付録デー 夕を用いて著者が作図)

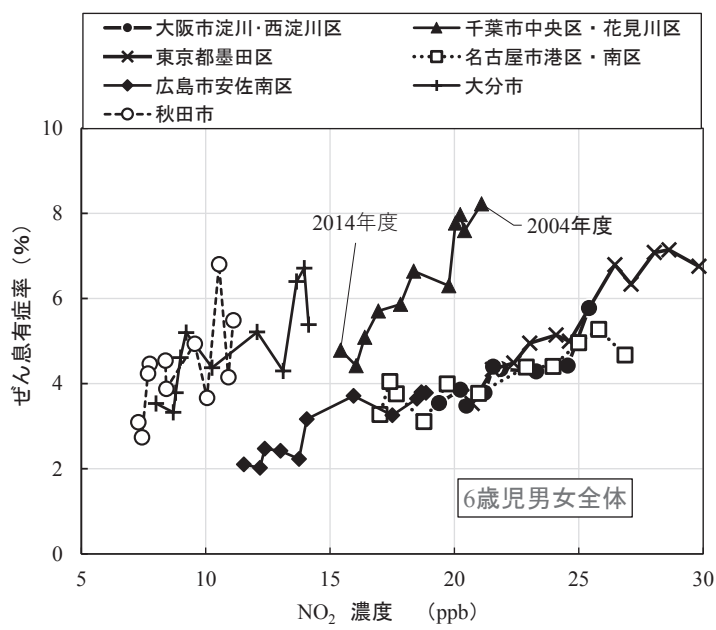

図7 2004 2014年度11年間の年次データでみた 調査対象地域別の $\mathrm{NO}_{2}$ 濃度とぜん息有症率 (調整率) の関係.（いくつかの地域の例）

症率の関係を，年次データでみると図 6 となる。 図 6 には 6 歳児と合わせて 3 歳児のデータも示し てあるが，いずれも正の相関関係にあることは明 らかであろう。

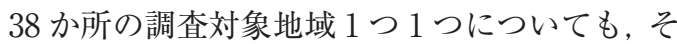
れぞれの年次デー夕を用いて $\mathrm{NO}_{2}$ 濃度とぜん息 
表 3 調査対象地域ごとに年次データでみた $\mathrm{NO}_{2}$ 濃度とぜん息有症率(調整率) との相関係数および有意水準

\begin{tabular}{|c|c|c|c|c|c|c|}
\hline \multirow{2}{*}{ 調査対象地域 } & \multicolumn{3}{|c|}{ 6歳児 (調整率、男女全体) } & \multicolumn{3}{|c|}{ 3歳巟 (調整率、男女全体) } \\
\hline & 回帰係数 & $\mathrm{P}$ 值 & $*(\mathrm{P}<0.05)$ & 回帰係数 & $\mathrm{P}$ 值 & $*(\mathrm{P}<0.05)$ \\
\hline 小樽市 & 0.33 & 0.099 & & \begin{tabular}{|l|}
0.33 \\
\end{tabular} & 0.0002 & $*$ \\
\hline 旭川市 & 0.6 & 0.085 & & 0.13 & 0.042 & $*$ \\
\hline 釧路市 & 0.88 & 0.29 & & & & \\
\hline 八戸市 & 0.43 & 0.043 & $*$ & 0.3 & 0.0011 & $*$ \\
\hline 秋田市 & 0.48 & 0.040 & $*$ & 0.49 & $3.4 \times 10^{-6}$ & $*$ \\
\hline 横手地域 & 0.36 & 0.16 & & 0.49 & 0.0001 & $*$ \\
\hline 佐野市 & 0.31 & 0.026 & $*$ & 0.2 & 0.013 & $*$ \\
\hline 草加市 & 0.23 & 0.0009 & $*$ & 0.14 & 0.0003 & $*$ \\
\hline 千葉市中央・花見川区 & 0.64 & $6.4 \times 10^{-6}$ & * & 0.41 & $2.9 \times 10^{-5}$ & * \\
\hline 柏・我孫子市 & 0.47 & 0.0005 & $*$ & 0.31 & $7.9 \times 10^{-7}$ & $*$ \\
\hline 墨田区 & 0.39 & $4.8 \times 10^{-6}$ & $*$ & 0.17 & $4.2 \times 10^{-5}$ & $*$ \\
\hline 中野区 & 0.45 & 0.0006 & $*$ & 0.15 & $1.7 \times 10^{-5}$ & $*$ \\
\hline 横浜市鶴見区 & 0.22 & 0.0029 & $*$ & 0.17 & $3.6 \times 10^{-7}$ & $*$ \\
\hline 川崎市幸区 & 0.3 & 0.0002 & $*$ & 0.17 & 0.0012 & $*$ \\
\hline 相模原市 & 0.18 & 0.0001 & * & 0.12 & $1.3 \times 10^{-5}$ & $*$ \\
\hline 高岡市 & 0.46 & 0.15 & & 0.39 & $8.9 \times 10^{-5}$ & $*$ \\
\hline 甲府市 & 0.1 & 0.30 & & 0.03 & 0.56 & \\
\hline 松本市 & 0.01 & 0.92 & & 0.01 & 0.91 & \\
\hline 岐阜市 & 0.12 & 0.033 & $*$ & 0.11 & 0.10 & \\
\hline 大垣市 & 0.15 & 0.029 & $*$ & 0.08 & 0.053 & \\
\hline 名古屋市港 - 南区 & 0.16 & 0.0009 & * & 0.1 & 0.0018 & $*$ \\
\hline 安城市 & 0.04 & 0.27 & & 0.04 & 0.11 & \\
\hline 東海市 & 0.23 & 0.005 & $*$ & 0.15 & 0.0018 & $*$ \\
\hline 四日市市 & 0.21 & 0.041 & $*$ & 0.19 & 0.0011 & $*$ \\
\hline 大阪市淀川・西淀川区 & 0.29 & 0.0013 & $*$ & 0.23 & $2.6 \times 10^{-5}$ & $*$ \\
\hline 堺市堺区 & 0.13 & 0.18 & & 0.04 & 0.35 & \\
\hline 大東市 & 0.1 & 0.20 & & 0.08 & 0.053 & \\
\hline 神戸市灘 · 兵庫区 & 0.24 & 0.31 & & 0.12 & 0.002 & * \\
\hline 尼崎市 ～～～～ & 0.39 & 0.0029 & $*$ & 0.02 & 0.72 & \\
\hline 西宮・芦屋市 & 0.28 & 0.011 & $*$ & 0.1 & 0.015 & * \\
\hline 和歌山市 & 0.43 & 0.003 & $*$ & 0.04 & 0.62 & \\
\hline 広島市安佐南区 & 0.23 & $8.0 \times 10^{-5}$ & * & 0.16 & $2.0 \times 10^{-6}$ & $*$ \\
\hline 宇部・山陽小野田市 & 0.39 & 0.10 & & 0.12 & 0.18 & \\
\hline 北九州市八幡西区 & 0.31 & 0.031 & * & 0.23 & 0.0052 & $*$ \\
\hline 福岡市南区 & 0.4 & 0.0037 & $*$ & 0.23 & $7.3 \times 10^{-5}$ & * \\
\hline 島原地域 & 0.39 & 0.0039 & $*$ & 0.28 & 0.0004 & $*$ \\
\hline 大分市 & 0.35 & 0.0054 & $*$ & 0.23 & 0.0002 & $*$ \\
\hline 那覇市 & 0.34 & 0.038 & $*$ & 0.27 & 0.037 & $*$ \\
\hline 全地域 & 0.3 & $3.4 \times 10^{-5}$ & $*$ & 0.17 & $1.0 \times 10^{-9}$ & $*$ \\
\hline
\end{tabular}

有症率との相関の有無を調べた。図 7 はいくつか の地域の例であるが, 明瞭な正の相関関係が読み 取れる。全地域について相関性を調べた結果は表 3 のようであり，多くの地域で正の有意な相関が 認められた。表 3 には 3 歳児の結果も示してある が， 6 歳児同様に明瞭な相関関係にあることがわ かった。 $\mathrm{NO}_{2}$ 濃度の減少傾向が続いているのは,
この間の窒素酸化物污染対策の効果だと考える と,「サーベイランス調査」のデータは $\mathrm{NO}_{2}$ 濃度 の低下とともに，ぜん息有症率が低下してきた経 過をよく捉えている。

Hasunuma, H, et al.（2014）は,「サーベイラン ス調査」の 3 歳児のデータを用いて独自の解析を 行っている。自動車 $\mathrm{NOx} \cdot \mathrm{PM}$ 法の対象地域と非 


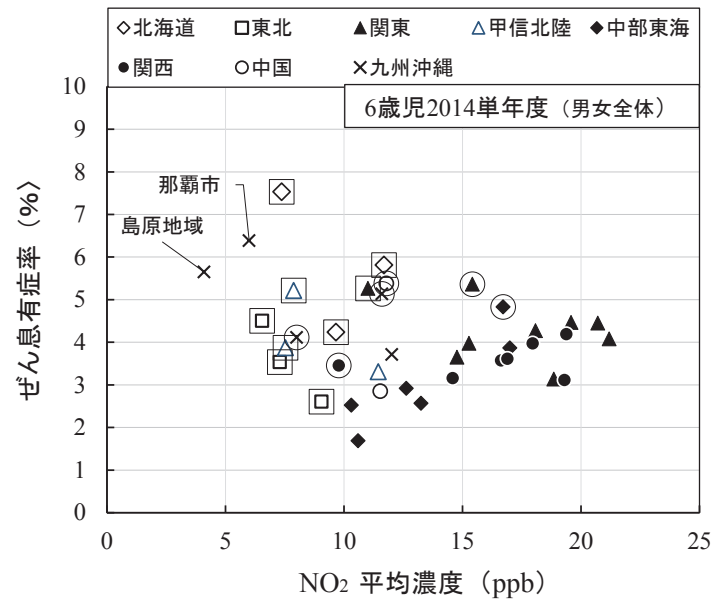

図 8 図 3 において寒冷気候地域（口囲み）およ び大規模な製鉄所・工業地帯が近接してい る地域（○囲み）を表示した図。

対象地域に分けて污染データの経年変化を比較 し, 非対象地域より対象地域の方が濃度の減少が 大きいことを明らかにし，それは同法による削減 対策の効果だと評価している。そしてその濃度と ぜん息有症率についてオッズ比の分析を行い, 有 症率と濃度の間に有意な正の相関がみられると述 ベている。

図 5, 図 6, 図 7 をみて注目されるべきは, $\mathrm{NO}_{2}$ 年平均濃度が $20 \mathrm{ppb}$ 以下に低下してもなお同じ 傾向で,ぜん息有症率が低下していることである。 これは $\mathrm{NO}_{2}$ 污染が現行環境基準ゾーンの下限レ ベルより低くなってもなお, ぜん息などへの健康 影響が生じている可能性を暗示している。

\section{4 もう一度図 3 (地域データによる地域横断的} 組合せ解析）を調べる

年次データによる経年縦断的解析では, 地域特 性がもたらす交絡影響を回避できたため, $\mathrm{NO}_{2}$ 濃 度とぜん息有症率は明瞭な正の相関関係にあるこ とが明らかとなった。そこで図 3 において地域特 性がどのように影響しているのか, もう一度吟味 した。その結果が図 8 である。取り上げた地域特 性の要因は 2 つ, 1 つは気候条件である。寒冷地 域では屋外大気污染だけでなく, 暖房や調理, 換 気状態による屋内污染も影響すると考えられたか らである（神ら 1997, 森ら 1986, 奥平・田中 2005,
鈴木ら 2016)。ここでは表 2 に示した $18^{\circ} \mathrm{C}$ デグリー デー值 1）が 2200 以上となる地域を寒冷地域とみ

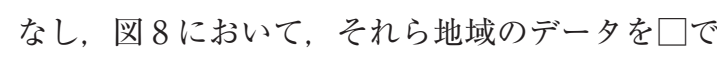
囲んだ。もう1つは製鉄所など大きな工業地带の 存在である。「調査報告 H26」の『地図表示』をみ ると千葉市中央区・花見川区など全部で 6 か所あ り，○で囲んだデータである。他にも地域特性は さまざまあり，とくに自動車交通の影響は小さく ないと思われる。『地図表示』からは自動車交通の 影響は特定できなかったので, ここでは取り上げ なかったが, 調査が必要である。

図 8 をみると, 上記 2 つ要因だけでも, ぜん 息有症率の高い地域, とくに $\mathrm{NO}_{2}$ 濃度の低い地域 のほとんどが該当していることがわかる。ただ図 中の島原地域, 那覇市は, これら 2 つ要因には 該当しないがぜん息有症率は例外的に高かった。 データ採取のあり方, アレルギー症既往歴調整の 問題, 他の污染物質の影響など他の要因を調べる 必要があろう。

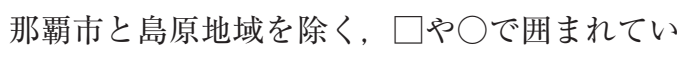
ないデー夕をみると, $\mathrm{NO}_{2}$ 濃度が高くなればぜん 息有症率が高くなる傾向が明瞭に読み取れる。と くに注目されるのは, 関東, 中部・東海, 関西に 属する調查対象地域の分布で，年次データでみた 図 5 のそれら 3 ブロックの分布と同様の傾向を示 していることである。したがって地域データによ る地域横断的解析でも, 気候条件などの地域特性 を考慮すれば，年次データによる経年縦断的解析 と矛盾しない。

「サーベイランス調査」が実施されるようになっ たのは, 中央公害対策審議会の答申 (中公審 1986) の中で「環境保健サーベイランス・システムの構 築」が提言されたことによる。そこには「疫学調査 においても, 一定の地域人口集団に対する縦断的・ 長期的観察が必要となる。すなわち, 現在の我が 国の大気污染の健康影響, 特に慢性閉塞性肺疾患 に対する影響は, 大気污染以外の要因と比べて主 たるものとは考えられないため, 従来多く行われて きた横断型の調査のみでは, 交絡現象等により, 十 分な評価究明が困難となっている」(下線は引用者 による) とあり, 提言においてすでに経年縦断的解 析の必要性が強調されていたのである。現在では 十分な年次データが蓄積され, 提言に応えること 
ができる段階に達している。「サベイランス調査」 データの適正な分析と評価が望まれる。

\section{5 オッズ分析による検討について}

「調查報告 H26」はオッズ比 ${ }^{3)}$ による検討（表 1 の解析 C) も行っている。ただ 38 調查地域すべて の対象者を一括した集団を対象に解析している。 このため対象者に対応させる $\mathrm{NO}_{2}$ 濃度は, 調査地 域に関係なく, 対象者が居住する 3 次メッシュの データであり，地域特性がもたらす交絡影響は除 去されないままである。オッズ比による検討は重 要な解析であるが, 地域特性の交絡影響が入った ままでは，的確な結果は得られない。したがって 本稿では,「調査報告 H26」のオッズ比による検討 の内容には言及しないことにした。オッズ比によ る検討は, 調査地域ごと, あるいはブロック分け するなど, 地域特性の影響を回避する必要がある。

\section{4 「ソラダス」にみる $\mathrm{NO}_{2}$ 濃度とぜん息有症 率の関係}

\section{1 「ソラダス」の調査方法}

$\mathrm{NO}_{2}$ 濃度の測定は, 天谷式簡易測定法の 3 型捕 集管（西川ら 1999）を用いている。大阪府全域の 3 次メッシュ(ただし大阪市域だけは 3 次メッシュ をさらに 4 分割した約 $500 \mathrm{~m}$ 四方の区画)に、メッ シュ当り捕集管 5 個を分散設置し, 5 個の平均值 でそのメッシュの $\mathrm{NO}_{2}$ 濃度としている。全メッ シュいっせい測定であり, 得られるデー夕は 1 日 平均濃度である。「サーベイランス調査」は推定濃 度であるが,「ソラダス」は実測データである。健 康アンケートは ATS-DLD 質問票に基づいた健康 アンケート用紙を作成し, $\mathrm{NO}_{2}$ 測定参加者および その家族や周辺の人たちを対象に配布回収してい る。捕集管設置数は「ソラダス」2012, 2016 でそ れぞれ 7180 個, 6982 個, 健康アンケート有効回 答数はそれぞれ 4444 人， 4873 人であった ${ }^{4)}$ 。

\section{2 「ソラダス」の主な調査結果}

$\mathrm{NO}_{2}$ 濃度測定結果をみると大阪市の濃度が最も 高く, 大阪市を中心に周辺に向かって濃度が低下 していく分布をしている。このような分布態様は 「ソラダス」開始以来約 40 年続いている。図 9 は 府域を大阪市, 大阪市隣接 10 市, およびその他地

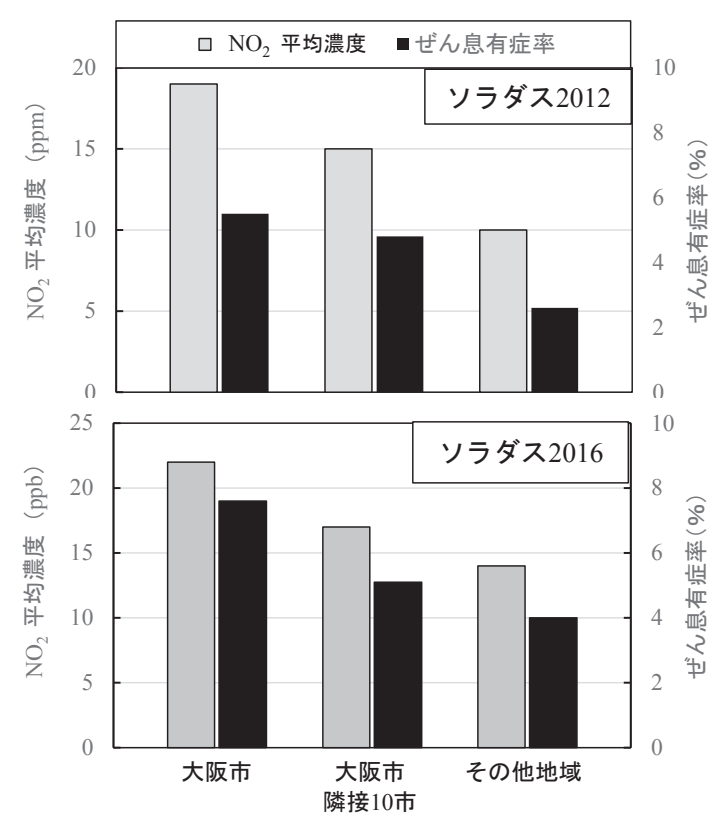

図 9 大阪府を 3 つの地域に分けた場合の $\mathrm{NO}_{2}$ 平 均濃度とぜん息有症率.

（大阪から公害をなくす会ウエブサイト資 料から引用)

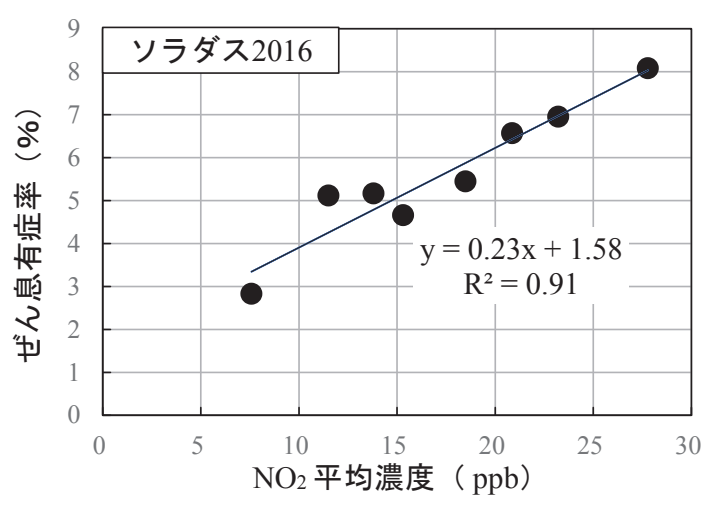

図 10 大阪府行政区を 8 つの群に分割した場合 の, 各群の $\mathrm{NO}_{2}$ 平均濃度とぜん息有症率 との関係（大阪から公害をなくす会ウエ ブサイト資料から引用)

域に 3 区分した場合の $\mathrm{NO}_{2}$ 濃度とぜん息有症率の 変化である。「ソラダス 2016」ではほぼ行政区全 体から健康アンケートが回収されたので，3区分 よりさらに細かく区分して有症率を求めることが できた。行政区を $\mathrm{NO}_{2}$ 濃度の順に並べ，8つの濃 度グループに区分した。図 10 はその結果である 
が, $\mathrm{NO}_{2}$ 濃度とぜん息有症率との間に正の相関関 係が認められた。

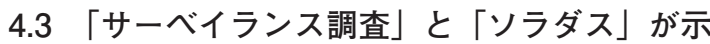 す $\mathrm{NO}_{2}$ 污染の現状}

「サーベイランス調查」と「ソラダス」, いずれ のデータにおいても, $\mathrm{NO}_{2}$ 濃度とぜん息有症率の 間に正の相関が存在することが見いだされた。互 いに無関係に行われた調査が同様の結果を示して いるわけで, 両調査によって, 現在もなお, ぜん 息に対して $\mathrm{NO}_{2}$ 污染が影響している可能性が否 定できないことが明らかになった。

$2 つ の$ 調査が示す, なお注目すべき結果は, $\mathrm{NO}_{2}$ 濃度とぜん息有症率の正の相関関係が，年平均濃 度 $20 \mathrm{ppb}\left(\mathrm{NO}_{2}\right.$ 環境基準のゾーン下限に相当）以 下になっても認められることである。これについ ては3つの要因が考えられる。

(1) $\mathrm{NO}_{2}$ 污染の健康影響が現行環境基準より もっと低い濃度まで存在する,

(2)平均濃度は低いが, その地域内に局所高濃度 污染が存在し，その健康影響が表れている，

(3)複数の污染物質による複合影響が存在し, そ の健康影響が表れている。

(1)については, $\mathrm{NO}_{2}$ の環境基準は当初日平均值 $0.02 \mathrm{ppm}$ であったものが, 1978 年に日平均值 0.04 〜0.06 ppm に緩和された経緯があり，これを考慮 すれば可能性はぬぐえない。

(2)については，現在の常時監視局網では局所高 濃度污染が捉えきれていない。環境省の「環境大 気常時監視マニュアル第 5 版」では, 都道府県ご との測定局の総数は, 人口 75,000 人当たり, ある いは可住地面積 $25 \mathrm{~km}^{2}$ 当たり 1 つとして, どちら か少ない方の数としている。大阪府を例にとると, 可住地面積約 $1320 \mathrm{~km}^{2}$, 人口約 886 万人で, 一般 環境測定局と自動車排出ガス測定局合わせて常時 測定局が 104 局設置されており, 面積当たりで上 記マニュアルを満足している。最近ではこれら常 時測定局の $\mathrm{NO}_{2}$ 測定值はすべて環境基準上限值 以下になってきている。しかし「ソラダス」の $\mathrm{NO}_{2}$ 測定結果では環境基準上限を超す局所高濃度污染 地点が見いだされている（大阪から公害をなくす 会ウエブサイト)。このことは, 現在の常時測定網 のデータだけによって, 大阪全域の $\mathrm{NO}_{2}$ 污染が環
境基準をクリアしたと評価するのは早計であり， 高濃度局所污染を把握できるような監視網の工夫 強化が必要であることを示している。

(3)については, 現在の大気污染の主要な污染源 は, 化石燃料の燃燒排ガスであり, $\mathrm{NO}_{2}$ 污染が存 在するということは同時に硫黄酸化物, 粒子状物 質，オキシダント原因物質などさまざまな物質に よる污染も生じていることを意味しており, $\mathrm{NO}_{2}$ 自体の健康影響に加えて, これら物質による複合 影響も考えられる。 $\mathrm{NO}_{2}$ 濃度が環境基準以下に なったから健康影響は生じないはずとみるのでは なく, $\mathrm{NO}_{2}$ 濃度は複合污染の指標という視点に立 つ必要があろう。

いずれにしても, 現在の $\mathrm{NO}_{2}$ 濃度レベルでもぜ ん息などへの健康影響が生じていることは否定で きず，污染の抑制・防止対策だけでなく，健康被 害に対する医療助成などの施策も検討されるべき であろう。

\section{5. 結 言}

環境省による「サーベイランス調査」と大阪の 住民らによる環境調査「ソラダス」, 両調査が示す $\mathrm{NO}_{2}$ 濃度とぜん息有症率の関係について調べた。 そして両調查結果からみた現在の $\mathrm{NO}_{2}$ 污染が提 起する問題について述べた。本稿で明らかになっ た点をまとめると以下のとおりである。

1 つは,「サーベイランス調查」は広域, 長期に わたるデータが収集, 蓄積されており, $\mathrm{NO}_{2}$ 濃度 とぜん息有症率の関連性を調べる解析は, 調查対 象地域ごとの地域データによる地域横断的解析, 年次デー夕による経年縦断的解析，いずれも可能 である。しかし大気污染物質濃度とぜん息有症率 との間に関連がみられなかったとする「調査報告 H26」のまとめは, 地域横断的解析のみに基づい たものであり，しかもその解析では気候条件など 地域特性がもたらす交絡影響について検討されて いないことがわかった。そこで気候条件など地域 特性がもたらす交絡影響の考慮，および「調査報 告 H26」では行われていない年次データによる経 年縦断的解析を行ったところ,「調查報告 H26」の まとめとは全く異なり,「サーベイランス調査」の データには, $\mathrm{NO}_{2}$ 濃度とぜん息有症率の間に明瞭 な正の相関関係が見いだされることがわかった。 
2 つは,「ソラダス」では 3 次メッシュの $\mathrm{NO}_{2}$ 濃 度が測定され, 並行して実施された呼吸器系に関 する健康アンケートによってぜん息有症率のデー 夕が得られている。これらデータの解析によって, $\mathrm{NO}_{2}$ 濃度とぜん息有症率の間に正の相関関係が見 いだされている。

3 つは,「サーベイランス調査」と「ソラダス」,

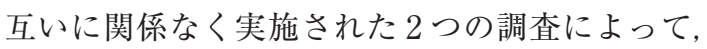
$\mathrm{NO}_{2}$ 濃度とぜん息有症率の間に正の相関関係が存 在すること, しかもその相関関係が現行環境基準 の下限よりも低いレベルまで続いていることが見 いだされた。このことは, 現在の $\mathrm{NO}_{2}$ 污染レベル でも, ぜん息などへの健康影響の存在が否定でき ないことを意味しており，注目される。

中央公害対策審議会の答申（中公審 1986）の提 言では「サーベイランス・システムは，(1)環境モ ニタリング, (2)健康モニタリング, (3)(1)および(2) からの情報を中心とするデータ・知見の集積, 解 析, 評価, (4)これらに基づく適切な対策の立案, 実施，の 4 つからなる」と述べられている。これ まで実施されてきた「サーベイランス調査」は(3) までであり，毎年の報告書にも(4)について具体的 な記述はみられない。しかし本稿で明らかになっ たことを受ければ，(4)が現実の課題として取り組 まれるべきであろう。提言では加えて「順次着目 する環境因子，健康因子とも拡大していくべきと 考える。さらに，このサーベイランス・システム においては, 専門委員会報告で留意事項とされた, 局地的污染の健康影響の評価がまず重視されるべ き」と指摘されている。この指摘も含めて「サー ベイランス・システム」の充実強化が望まれる。

\section{注}

1 ）ATS-DLD 質問票に基づいた健康調査について, 「調査報告 H26」の用語説明は以下である。1 1978 年 に米国胸部疾患協会 (American Thoracic Society) が米国立心臓・血液 研究所の肺疾患部門 (National Heart, Lung, Blood Institute, Division of Lung Disease)の委託により開発したATS-78 標準質問票 をもとに, 環境庁委託研究で日本語版が作成され, 多くの地域におけるパイロット調查の結果を踏ま えて改良されたものが，いわゆる環境庁版 ATS 呼 吸器症状質問票である。平成 8 年より開始した本調 査では, 調查対象者への負担を軽減し, 協力率を向
上するため, パイロット調査により妥当性を検証し た簡易質問票を使用している.

2) $18^{\circ} \mathrm{C}$ デグリーデーとは, 基準温度を $18^{\circ} \mathrm{C}$ とし, 日 平均気温が $10^{\circ} \mathrm{C}$ 以下となる初日から終日までの期 間 (暖房期間) の間の $18^{\circ} \mathrm{C}$ と日平均気温との差の積 算值のことで, 暖房負荷を表す指標の 1 つ。デー夕 は, HEAT 20 ウエブサイト気象デー夕資料から引 用した。

3 ）オッズ比について,「調查報告 H26」の用語説明 は以下である。ある事象の確率（p）と起こらない 確率（1-p）との比 (p/(1-p)) をオッズという. オッズ比とは, ある疾患などへの罹りやすさを $2 つ$ の群で比較して示す統計学的な尺度で, 群 1 のオッ ズ (p1/(1-p1)) と群 2 のオッズ (p2/(1-p2))の 比 $(\mathrm{p} 1 /(1-\mathrm{p} 1)) /(\mathrm{p} 2 /(1-\mathrm{p} 2))$ で定義される. オッズ比が 1 とは，ある疾患への罹りやすさが両軍 で同じということであり，1より大きいとは，疾患 への罹りやすさがある群で高いことを意味する，逆 にオッズ比が 1 より小さいとは, ある群において疾 患に罹りにくいことを意味する.

4 ）「ソラダス」全般㧍よび「ソラダス 2016」の詳細 については, 大阪から公害をなくす会のウエブサイ トを見てください（URLは文末に記載）.

\section{引用文献}

中央公害対策審議会 (1986)「公害健康被害補償法 第一種地域のあり方等について」VII章の 4 , 今後 の環境保健に関する施策。

Hasunuma, H, Ishimaru, Y., Yoda, Y., Shima, M. (2014), "Decline of ambient air pollution levels due to measures to control automobile emissions and effects on the prevalence of respiratory and allergic disorders among children in Japan”, Environmental Research, NO.131, pp.111-118.

神 和夫・小林 智・堀 義宏・都築俊文 (1997) 「冬季における札棍市の住宅内外の二酸化窒素 濃度と個人曝露濃度」『北海道衛研所報』 47 号, pp.52-56.

環境省環境保健部（2016）『平成 26 年度 大気污 染に係る環境保健サーベイランス調査報告』。 久志本俊弘・西川榮一 - 喜多善史 · 岩本智之 - 中 村 毅・中森芳明・後藤隆雄・長野晃 (2013) 「住民による大阪府全域の大気污染測定運動ソ ラダス」『人間と環境』第 39 巻第 3 号, pp.1926. 
久志本俊弘 (2018)「大阪での住民による $\mathrm{NO}_{2}$ 簡 易測定の経過と健康影響調查一 $\mathrm{NO}_{2}$ 濃度と健康 影響との相関」『日本の科学者』第 53 巻第 5 号, pp.4-9.

森 忠司・吉川政雄・松下秀鶴（1986）「 $\mathrm{NO}_{2}$ の 個人被曝量に及ぼす各種生活空間の影響」『大気 環境学会誌』第 21 巻第 5 号, pp.446-453.

西川榮一・伊藤幸二 ・ 久志本俊弘 - 後藤隆雄 $\cdot$ 長 野 晃 (1999)「天谷式 $\mathrm{NO}_{2}$ サンプラーの捕集 特性と精度評価」『人間と環境』第 25 巻第 3 号, pp.102-114.

西川榮一 (2018)「「サーベイランス調査」にみる $\mathrm{NO}_{2}$ 污染の健康影響」『日本の科学者』第 53 巻 第 5 号, pp.10-11.

奥平純子・田中恒雄（2005）「居住環境における二 酸化窒素の挙動」『室内環境学会誌, 』第 8 巻第 1 号, pp.27-34.

小野雅司 (2014)「大気污染と環境保健サーベイラ ンス調査一調査の概要と結果について一」『アレ
ルギー・免疫』第 21 巻第 10 号, pp.54-65.

鈴木義史 - 橘 健太 - 丸尾容子 - 柳沼 優, · 菊池 蓮・中野智保（2016）「仙台市の家庭における冬 季室内二酸化窒素濃度の調査」『室内環境』第 19 巻第 2 号, pp.121-130.

平成 26 年度 大気污染に係る環境保健サーベイラ ンス調査報告の URL

http://www2.env.go.jp/library/opac/Holding_ list/search?rgtn=221292 (2017.10.10 閲覧).

HEAT 20: 2020 年を見据えた住宅の高断熱化技術 開発委員会のウエブサイト資料

http://www.heat20.jp/2015_Reference_ Weather_data.pdf (2017.10.10 閲覧).

大阪から公害をなくす会: 第 8 回大阪 $\mathrm{NO}_{2}$ 簡易測定 運動（ソラダス 2016）調査報告

http://oskougai.com/modules/maincontents/ content0073.html (2017.10.10 閲覧).

(2018 年 9 月 13 日受付, 2019 年 4 月 11 日受理) 